\title{
Mükerrer Suçluluk, Davranım Bozukluğu ve Antisosyal Kişilik Bozukluğu'nun Ortak Değişkenleri Üzerine Bir Derleme
}

DOI: $10.26466 /$ opus.687095

\author{
Beril Yavuz Bozdoğan* - Müjdat Avc1 ** \\ * Araş. Gör., Osmaniye Korkut Ata Üniversitesi, Sağlık Bilimleri Fakültesi, Osmaniye/Türkiye \\ E-Posta: berilyavuz08@gmail.com \\ ORCID: 0000-0002-7014-7046 \\ ** Doç. Dr., Osmaniye Korkut Ata Üniversitesi, Sağlık Bilimleri Fakültesi, Osmaniye/Türkiye \\ E-Posta: mujdatavci24@gmail.com ORCID: 0000-0003-4409-4523
}

$\ddot{O} z$

Bu çalışmada, mükerrer suçluluğun Davranım Bozukluğu, Antisosyal Kişilik Bozukluğu gibi psikopatolojik rahatsızlıklar ile olan ilişkisi incelenmiştir. Çalışma kapsamında Davranım Bozukluğu ve Antisosyal Kişilik Bozukluğu tanısı alan bireylerin suç işleme oranları, ne tür suçlar işlemeye meyilli olduklar ve suç örüntülerini inceleyen çalışmalardan bahsedilmiştir. Antisosyal Kişilik Bozukluğu ile mükerrer suçluluk arasındaki ilişki boylamsal çalışmalar ışığında ele alınmıştır. Söz konusu bu çalışmada; suçun tekrarlı bir örüntü haline gelmesine etki eden mekanizmalar Davranım Bozukluğu ve Antisosyal Kişilik Bozukluğu gibi psikolojik bozukluklarda hesaba katılarak değerlendirilmiştir. Çalışmada, mükerrer suçluluğun Davranım Bozukluğu ve Antisosyal Kişilik Bozukluğu'nun ortak risk faktörleri olarak; yaş durumu, işlenen ilk suçun niteliği, aile tutumu, aile yapısı faktörleri, sosyoekonomik faktörler, zekâ ve okul başarısı gibi çeşitli faktörler incelenmiştir. Ek olarak, antisosyallik kavramının mükerrer suçlulukla ilişkisinin daha kapsaml incelenmesi amacıyla bu çalışma içerisinde Yaşam Boyu Kriminoloji Teorilerine yer verilmiştir. Yaşam Boyu Kriminoloji Teorileri arasinda yer alan Entegre Bilişsel Antisosyal Potansiyel Teorisi (Integrated Cognitive Antisocial Potential Theory, ICAP) ve Gelişimsel Sinıflandırma Teorisi; mükerrer suçluluğun gelişimine etki eden faktörleri antisosyallik kavramı üzerinden ele alarak, iki kavramın birbiriyle olan ilişkisinin daha să̆lam temeller üzerine oturtulmasında yardımcı olmaktadır.

Anahtar Kelimeler: mükerrer suçluluk, kronik suçluluk, davranım bozukluğu, antisosyal kişilik bozukluğu 


\title{
A Review on the Common Variables of Repetitive Guilt, Behavioral and Antisocial Personality Disorders
}

\begin{abstract}
In this study, the relationship of repeated criminality with psychopathological disorders such as Behavioral Disorder and Antisocial Personality Disorder was investigated. Within the scope of the study, it was mentioned about the individuals who were diagnosed with Conduct Disorder and Antisocial Personality Disorder, their crime rates, what kind of crimes they tend to commit, and the studies examining crime patterns. The relationship between Antisocial Personality Disorder and repeated guilt has been addressed in the light of longitudinal studies. In this study; The mechanisms that affect the repetitive pattern of crime were evaluated by taking into account psychological disorders such as Conduct Disorder and Antisocial Personality Disorder. In the study, the common risk factors of the Conduct Disorder and Antisocial Personality Disorder; Various factors such as age status, quality of the first crime committed, family attitude, family structure factors, socioeconomic factors, intelligence and school success were examined. In addition, in this study, Lifelong Criminology Theories are included in this study in order to examine the relation of the concept of antisociality with the repeated criminality. Integrated Cognitive Antisocial Potential Theory (ICAP) and Developmental Taxonomy Theory, which are among the Lifelong Criminology Theories; By addressing the factors that affect the development of repetitive criminality through the concept of antisociality, it helps to establish the relationship between the two concepts on more solid foundations.
\end{abstract}

Keywords: repetetive guilt, chronic guilt, behavioral disorder, antisocial personality disorder 


\section{Giriş}

Suç insan doğasının bir parçasıdır. Dolayısıyla, insanın yeryüzüne ayak bastığı andan itibaren var olan ve hem insanın söz konusu doğasını hem de tarihsel süreç içerisindeki serüvenini dikkate aldığımızda, türü, şekli değişse de var olmaya devam edecek bir olgudur. İnsanın doğasında var olan toplum halinde yaşama isteği aynı zamanda beraberinde rekabet, mücadele ve benzeri sosyal olguların da ortaya çıkmasına yol açmıştır. Toplumsal yaşam her zaman bir denge halinde olamayacağından bu mücadele ve rekabet sürecinde ister istemez toplumsal düzene aykırı ya da normlardan sapan davranışlar da ortaya çıkmıştır. Bu norm dışı davranışların bir kısmı ise farklı toplum ve zaman dilimlerinde "suç" kavramıla ifade edilmiştir (Dönmezer, 1994). Genel itibariyle hukuka ve yasalara aykırı olan, toplumun düzenini zedeleyen eylemler olarak tanımlanan suç (Anayurt, 2001), sadece hukuki bir sorun olarak gözükse de sosyolojik, psikolojik, kültürel vb. boyutları da olan bir olgu olarak toplumların gündeminde yer almıştır (Saldırım ve Karacık, 2001).

Suç kavramı üzerine literatürde yapılmış olan araştırmalarda suçluluk durumunu etkileyen çeşitli değişkenlere odaklanılmıştır. Bunlar sosyal, ekonomik, demografik ve çevresel değişkenlerdir. Dolayısıyla, konuya ilgi duyulmaya başlandığı ilk dönemlerde, olgu, bu değişkenlerin birbirleri ile olan etkileşimleri çerçevesinde çözümlenmeye çalışılmıştır (Muş, 2016). 20. yüzyılın ilk yıllarından itibaren suçluluk olgusu üzerine yapılan çalışmaların odak noktası değişime uğramıştır. Bu bağlamda kişilerin içsel süreçlerinin ve psikolojik özelliklerinin de suça eğilim gösteren edimlerin açılanmasında etkili olabileceği fark edilmiştir (Yılmaz, 2018).

Toplumda karşılaşılan pek çok suçlu davranışın arka planında çeşitli psikolojik rahatsızlıkların olduğu yapılan araştırmalarla ortaya konmaktadır. Bu bağlamda, Şizofreni, Bipolar Bozukluk ve Depresyon gibi psikolojik rahatsızlıkların suça ve şiddete olan eğilimi arttırdığı görülmektedir. Literatürdeki çalışmaların büyük bir kısmında alkol ve madde bağımlılı̆̆ı, şizofreni ve antisosyal kişilik bozukluğu tanısına sahip olanların yüksek ölçüde suç ile ilintili oldukların tespit edilmesi konuyla ilgili önemli bulgular olarak belirtilebilir (Brennan, Mednick ve Hodgins, 2000; Kalenderoğlu, Yumru, Selek ve Savaş, 2007). 
Kişilik bozuklukları ve suç ilişkisi ele alındığında Antisosyal Kişilik Bozukluğu $(\mathrm{AKB})$ en çok ilgi gören kişilik bozukluğu olmuştur (Hare ve Neumann, 2009; Öncü vd., 2002). Hastanelere yatış yapmış ve adli gözlem altında bulunan hastaları \%30,2'sinin AKB tanısına sahip olmaları, yine bir başka çalışmada, hüküm giymiş bireylerin \%71'ine AKB tanısının konduğunun saptanması konuyla ilgili verilebilecek örneklerdir. Bulgular değerlendirildiğinde $\mathrm{AKB}$ tanısını alan bireylerin diğer hüküm giyenlere oranla çok daha erken yaşta suç işlemeye başladıkları ve suç işleme davranışlarının çeşitlilik göstererek süreklilik arz ettiği görülmüştür (Algül vd., 2007). Alan yazında yapılmış olan araştırmalar neticesinde AKB tanısına sahip olmanın suç işleme davranışının güçlü bir yordayıcısı olduğu anlaşılmaktadır (Öncü vd., 2002). AKB tanısı diğer kişilik bozuklukları ile komorbite halinde görülmektedir. AKB tanısına en çok eşlik eden ikinci tanı madde kullanım bozukluğu, üçüncüsü ise şizofrenidir (Algül vd., 2007).

AKB tanısına sahip bireylerin suç işleme örüntüsü diğer suçlulardan farklılaşmaktadır. AKB tanısına sahip birey daha çok tekrarlayan suça eğilimli olmaktadır. Literatürde bulunan bazı çalışmalara bakıldığında $A K B$ ve Davranım Bozukluğu tanısı olan suçluların, suç örüntülerinin tekrarlı olduğu, dolayısıyla mükerrer suçluluk kavramıyla ilintili oldukları düşünülmektedir (Algül vd., 2007).

Mükerrer kelime anlamı olarak tekrarlanan anlamına gelmektedir. Mükerrer suçluluk ise suçun sürekli olarak tekrar etmesi, suç davranışının sürekli hale gelmesi olarak tanımlanmaktadır (Cömert, 2018). Mükerrer suçluluğun temel değişkenlerinden bir tanesinin geçmişten gelen antisosyal davranış örüntüleri olduğu kabul edilmektedir (Duncan, Kennedy, ve Patrick, 1995). Farrington ve arkadaşları (1983) tarafından yapılan araştırmalara göre; çocukluk döneminde görülen davranışsal ve dürtüsel problemlerin ileri yıllarda ortaya çıkacak olan suçluluk durumunun güçlü bir yordayıcısı olduğu belirtilmektedir. Bireyin çocukluk ve gençlik yıllarındaki uyumcu olmayan ve otoriteye meydan okuyan antisosyal tutumları onun mükerrer suçlu olma ihtimallerini büyük oranda arttırabileceği ileri sürülmektedir (Kızmaz, 2006).

$\mathrm{Bu}$ bilgilerden hareketle bu çalışmanın temel amacı, tekrarlayan suç örüntüsüne sahip, kronik olarak suç işleme davranışı sergileyen bireylerin Antisosyal Kişilik Bozukluğu ve Davranım Bozukluğu ile olan ilişkisini belirlemektir. Ayrıca mükerrer suçluluğa dair erken dönem risk faktörlerini 
AKB ve davranım bozukluğu açısından değerlendirmektir. Mükerrer suçluluğu, AKB ve davranım bozukluğunu yordayan bazı değişkenler ortaktır. $\mathrm{Bu}$ durumda antisosyal kişilik bozukluğu ve davranım bozukluğu tanısına sahip olmanın kısmen de olsa bazı noktalardan mükerrer suçluluğa açıklama getirebileceği ileri sürülmektedir. Araştırmada suçu kronik olarak deneyimlemenin antisosyal kişilik bozukluğu ve davranım bozukluğu açısından nasıl değerlendirildiği çeşitli çalışmalar ve teorilerle örneklendirilerek açıklanmaya çalışılacaktır.

\section{Literatür Taraması}

Mükerrer suçluluk ve antisosyal kişilik bozukluğu ile ilgili yurt içinde ve yurtdışında yapılmış çeşitli çalışmalar söz konusudur. Örneğin yurtiçi literatürde yapılan bir araştırmada, bireyin antisosyal kişilik bozukluğu, madde kullanımı veya mental retardasyon tanılarının olmasının yineleyici suç işleme oranın yükselttiği tespit edilmiştir (Maner, Kayatekin, Abay, Saygılı ve Sener, 1991). Literatürde yer alan bir başka çalışmada ise, psikiyatrik tanı nedeniyle ceza ehliyeti olmayan bireylerin zorunlu aldıkları tedavi sonrasındaki yineleyici suç oranları araştırılmıştır. Çalışmanın sonucunda; sürekli olarak yineleyici suç işleyenlerin antisosyal kişilik bozukluğu, madde ve alkol bağımlılığı ve duygu durum bozuklukları tanıları ile ilintili oldukları saptanmiştır (Öncü vd., 2002).

Yurtdışı literatürde yapılan boylamsal bir çalışmada, antisosyal kişilik bozukluğu tanısına sahip olanların da yer aldığı toplam 1095 suçlu 20 yıl boyunca işledikleri suçlar yönünden gözlemlenmiştir. Çalışmada AKB tanısına sahip suçluların \%38,7'sinin sürekli suç işleme davranışını tekrar ettikleri; AKB tanısına sahip olmayan suçluların ise $\% 24,7^{\prime} \operatorname{sinin}$ yineleyici suç işlediği tespit edilmiştir. Bu çalışmanın sonucunda $\mathrm{AKB}$ tanısına sahip bireylerin suçu yineleme oranının daha fazla olduğu sonucuna varılmıştır (Fridell, Hesse, Jæger, ve Kühlhorn, 2008). Yapılan bir diğer araştırmada ise, suç işlemiş olan 12-15 yaş arasındaki çocukların \%43'ünde Davranım Bozukluğu ve Dikkat Eksikliği ve Hiperaktivite Bozukluğu (DEHB) eş tanısı görülmüştür. Bu çalışma içerisinde tekrarlayan suç oranı ise, \%32,7 olarak tespit edilmiştir. Sonuçlar incelendiğinde tekrarlayan suçların daha çok hırsızlık ve darp kategorisinde olduğu görülmüştür. Tekrarlayan suçlar grubunda olan çocuklarda okul başarısızlığı, alkol ve madde kullanımı, 
ebeveynlerin akraba evliliği yapmış olması ve birinci dereceden yakın akrabalarda suç işlemiş bireylerin bulunduğu belirlenmiştir. Bu çerçevede, mükerrer suçluluğa eğilimi olan çocukların davranım bozukluğu tanısı alma olasılıklarının diğerlerine göre daha yüksek olduğu söylenebilir (Güler, 2017). Bu ve literatürdeki konuyla ilgili diğer çalışmalara bakıldığında mükerrer suçluluğun antisosyal kişilik bozukluğu ve davranım bozukluğu ile yakından ilintili olduğu açıkça görülmektedir.

\section{Konu İle İlgili Temel Kavramlar}

\section{Antisosyal Kişilik Bozukluğu ve Davranım Bozukluğu}

Toplumsal normlara uyum göstermekte zorlanan, toplumsal normlar tarafından suç sayılan davranışları sürekli olarak tekrar eden bireyler Antisosyal Kişilik Bozukluğu (AKB) tanısı almaktadır. Bu tanıya sahip olan bireyler, aile ve toplumsal yaşamda gerekli sorumluluğu üstlenemeyen, dürtüsel hareket eden, çoğunlukla saldırgan davranışlar sergileyen kişilerdir. Bu bireyler, sergiledikleri suçlu davranışlardan pişmanlık duymazlar ve özdenetimleri zayıftır dolayısıyla, ceza alsalar dahi yeniden suçlu davranışlara yönelmeleri çok olasıdır. Antisosyal Kişilik Bozukluğu tanısına sahip bireyler 18 yaşından önce davranım bozukluğu tanısını alırlar (Öztürk ve Uluşahin, 2016).

Davranım Bozukluğu, insanların temel hak ve özgürlüklerini, toplumun kurallarını ihlal edecek türden, sürekli ve tekrarlayan davranış örüntülerini barındıran psikolojik bir rahatsızlıktır (Mutlu, Özdemir, Yorbik, ve Kilicoglu, 2015). Davranım Bozukluğu ve Antisosyal Kişilik Bozukluğu tanısı psikiyatrlar tarafindan Mental Bozuklukların Tanısal ve Sayımsal El Kitabı (The Diagnostic and Statistical Manual of Mental Disorders, DSM-5)'nda bulunan kriterlere göre konulmaktadır. DSM-5'e göre; davranım bozukluğu tanısı için sağlanması gereken 15 tanı ölçütü dört temel başlık altında toplanmıştır. Başlıklar şu şekildedir; insanlara ve hayvanlara yönelik saldırgan tavırlar, eşyalara zarar verme, dolandırıcılık ya da hırsızlık davranışlarını göstermek ve kuralları büyük ölçüde çiğnemektir (Öztürk ve Uluşahin, 2016).

Dört temel başlık altında bulunan maddelere baktığımızda kabadayılık, gözdağı verme, kavga başlatma, kavga içerisinde kesici, delici alet (bıçak, 
kırılmış şişe, silah, sopa, taş vb.) taşıma, insanlara ve hayvanlara karşı acımasız, zarar veren tutum ve davranışlar sergileme, başkasının gözü önünde çalma (silahlı soygun vb.), cinsel taciz, haneye tecavüz (eve veya arabaya izinsiz, zarar vermek için girme vb.), sürekli yalan söyleme, diğer kişileri manipüle ederek kandırma, isteyerek yangın başlatma, 13 yaşına gelinmesiyle birlikte geceyi dışarda geçirme, iki kez evden kaçma veya bir kez uzun aralıkla eve gelmeme, 13 yaş öncesinde sürekli olarak okuldan kaçma davranışlarından üç tanesini bir yıldır ve en az bir tanesini son 6 aydır sürekli ve tekrarlayan biçimde sergiliyor olmak davranım bozukluğu tanısı için yeterlidir. Önemli bir nokta ise bu davranışların kişinin iş, okul ve sosyal hayatını bozuyor olmasıdır. Kişi 18 yaşında veya daha büyük ise ve davranım bozukluğ tanısı kriterlerini karşılıyorsa, o zaman, Antisosyal Kişilik Bozukluğu tanısı almaktadır (Öztürk ve Uluşahin, 2016).

\section{Suç ve Mükerrer Suçluluk}

Suç, toplumun yapısına zarar veren, bu zararın kanunlar tarafından açıkça görüldüğü eylemler bütünüdür. Jhering, suçu toplumun birlikte yaşama düzenine aykırı olan bir saldırı olarak tanımlamaktadır. Thomas ve Znaniecky'ye göre suç bireyin aidiyet hissettiği grupta, toplum dayanışmasıyla ters düşen eylemlerdir. Dönmezer'e göre suç, suç işleyen bireyin içsel dünyası ile bağlantılıdır ve aynı zamanda bireyin kişilik yapısı hakkında ipucu vermektedir (Dönmezer, 1994).

Mükerrer suçluluk, bir kez suç işledikten ve cezaevinden çıktıktan sonra yineleyici biçimde suç işleyen bireyleri nitelendirmektedir. Dolayısıyla mükerrer suçlular, kronik olarak yeniden suç işleme davranışını gerçekleştirirler (K1zmaz, 2007).

\section{Mükerrer Suçluluk ve Davranım Bozukluğunu Yordayan Faktörler}

Mükerrer suçluluğun temel değişkenlerinden bir tanesinin geçmişten gelen antisosyal davranış örüntüleri olduğu kabul edilmektedir (Duncan vd., 1995). Bir kez suç işlemiş bireylerin bu eylemlerini kronik suç işleyen bir örüntü haline getirmelerinde belli başlı değişkenlerin etkisinden bahsedilmektedir. Suç işlemiş bireylerin cinsiyetinin erkek olması ve bekar olması mükerrer suçlu olma potansiyelini güçlü biçimde yordamaktadır. Öte yan- 
dan, suçlu kişinin suç işleme yaşı mükerrer suçluluğun en önemli yordayıc1larından biri olarak kabul edilmektedir (Kızmaz, 2006).

\section{Yaş Faktörü}

Literatürde bulunan araştırmalar, tekrarlayan suç oranlarının erken yaşlarda daha sik görüldüğünü belirtmektedir (Kızmaz, 2006). Bu durum erken yaşlarda tekrarlayan suç örüntüsüne sahip olan çocukların davranım bozukluğu tanısı alabilecekleri ihtimalini düşündürmektedir. Suç işlemiş çocukların birçok davranışı davranım bozukluğu tanı maddelerini karşılamaktadır. Davranım Bozukluğu tanısına sahip olan çocuklarda çocuk suçluluğu 13-16 yaş aralığında en yüksek sıklık derecesine ulaşmaktadır. Yaş aralığına göre işlenen suç türü değişiklik gösterebilmektedir. Mağaza ve dükkanlardan bir şeyler çalma ve yıkıcı tutumlar 11 yaşından önce, evlere girerek hırsızlık yapma ve araba hırsızlığı yapma eylemlerinin ise ortalama 14-15 yaş civarında görülmeye başlandığı bildirilmektedir. Diğer taraftan cinsel ve uyuşturucu madde satıcılığı suçları ise ortalama 17-19 yaş aralığında ortaya çıkmaktadır (Murray ve Farrington, 2010). Bununla birlikte Cambridge Üniversitesi'nde yapılmış olan bir araştırmada ilk suçunu 10-13 yaş arasında işleyen ve mahkumiyet alan erkek çocukların 13 yıl boyunca tekrarlayan suç örüntüsünü devam ettirdikleri gözlemlenmiştir (Farrington vd., 2006).

\section{İşlenen İlk Suç Faktörü}

Mükerrer suçluluğun önemli değişkenlerinden bir tanesi işlenen ilk suçun türüdür. Mükerrer suçlularda mükerrer olmayan suçlulara göre daha çok eşyaya/mala yönelik hırsızlık ve çalma davranışı örüntüsü görülmektedir. Londra'da ve Stockholm'de yapılan çalışmalarda 10-12 ve 13-16 yaş aralığındaki tekrarlayan suç örüntüsüne sahip çocukların ilk işledikleri suçların hırsızlık olduğu tespit edilmiştir (Farrington ve Wikstrom, 1994). Bu bulgu davranım bozukluğu tanısına sahip çocukların ilk suçlarının hırsızlık olmasıyla örtüşmektedir (Murray vd., 2010). 


\section{Aile Tutumu ve Aile Yapısı Faktörleri}

Mükerrer suçlular üzerinde yapılan çalışmalarda ebeveynlerden birinin veya her ikisinin de suçlu olma durumu, suç örüntülerinin varlığının, aile içerisinde bir veya birkaç kişinin suçlu olmasının; bireyin suç işlemesini ve tekrarlayan suç örüntüsüne sahip olmasını güçlendiren etmenler olduğu görülmüştür. Ek olarak reddeci, yetersiz, ilgisiz, güvenli bağın kurulamad1ğı aile ortamında yetişen çocukların mükerrer suçluluğa daha yatkın oldukları gözlemlenmiştir. Yine mükerrer suçluların genel aile yapısı incelendiğinde boşanma, ölüm veya tek bir ebeveynle yaşıyor olma durumunun varlığı da gözlemlenmiştir (Farrington, 2005).

Aile süreçleri davranım bozukluğu açısından da risk faktörleri oluşturmaktadır. Yapılan bir meta analiz çalışmasının sonucunda, ailenin pekiştirme ve cezalandırma tutumlarının ve aile yapısının çocuklardaki antisosyal davranış örüntüleri ile ilişkili olduğu bulunmuştur (Rothbaum ve Weisz, 1994). Çocuklardaki davranım bozukluğu tanısını tahmin eden en önemli aile faktörü, ailenin çocuğu zayıf yönlendirme özelliğine sahip olmasıdır. Başka bir ifadeyle, ebeveynlerin çocuğun ihtiyacı olan disiplini doğru ve yeterli bir biçimde sağlayamadıkları ve her çocuğun temel ihtiyacı olan duygusal ihtiyaçları da karşılayamadıkları görülmüştür. Katı ve cezalandırıc bir tutum sergileyen ailelerde yetişen çocukların davranım bozukluğu tanısı alma ve tekrar eden suç örüntüsü geliştirme riski yüksek bulunmuştur. Literatürde yer alan çalışmalarda katı tutuma ek olarak reddedici tutumla ve fiziksel şiddetle büyüyen çocukların suç işleme oranlarının daha yüksek olduğu tespit edilmiştir (McCord, 1979; Robins, 1978). Bunun yanında çocuklukta fiziksel şiddete uğramış suçluların ilerleyen dönemlerde daha çok şiddet içerikli saldırgan suç örüntüsüne sahip oldukları belirlenmiştir (Loeber ve Farrington, 1998).

Davranım Bozukluğuna sahip bireylerin aile yapısı incelendiğinde göze çarpan ilk durum mutsuz ilişkiye sahip anne ve babalarının olmasıdır (Loeber ve Farrington, 1998). Ailede ayrılma ve ölüm gibi durumlar, çocuğun tek bir ebeveynin kontrolünde yetişmesi davranım bozukluğunu yordamaktadır. Yapılan araştırmalarda çocuğun tek ebeveyn ile yetişmesi durumuna ailenin düşük gelir düzeyi de eşlik ediyorsa bu değişkenlerin davranım bozukluğunun yordayıcısı olabileceği belirtilmiştir. Ebeveynlerin ayrılmasından sonraki süreçte bir daha evlilik yapmayan anne ile birlikte ya- 
şayan çocuklarda davranım bozukluğu görülme riskinin daha fazla olduğu ifade edilmiştir. Ebeveynlerin antisosyal örüntüye sahip olmasl, antisosyal bozukluğun ve davranım bozukluğunun en önemli yordayıcılarından biri olarak görülmektedir (Murray ve Farrington, 2010).

\section{Sosyo-ekonomik Faktörler}

Düşük gelir düzeyi ve anne babanın düşük eğitim düzeyi suçluluk örüntüsünü ve davranım bozukluğunu tahmin eden etmenler arasında yer alırlar. Literatürde bulunan çeşitli araştırmalara göre, düşük sosyo-ekonomik düzey ile antisosyal davranışlar arasındaki ilişki ailenin uyumlu davranışlarıyla da bağlantılıdır. Öyle ki, düşük sosyo-ekonomik düzey, davranım bozukluğu ve suçluluk durumunu yordamaktadır. Çünkü düşük sosyo-ekonomik düzeye sahip aileler aynı zamanda düşük seviyede ebeveynlik yeteneği sergilemektedirler (Murray vd., 2010). Buna karşılık çocukların yetiştirildiği ortamda aile içi iletişim ve ebeveynlik yetenekleri iyi durumdaysa düşük sosyo-ekonomik düzey ile suç işleme davranışı arasında güçlü bir ilişkinin olmadığı tespit edilmiştir (Ak ve Sayar, 2002).

Yapılan bir çalışmada 6 yaşına kadar düşük sosyo-ekonomik düzeyde yer alan, cezalandırmada fiziksel şiddetin kullanıldığ 1 ve reddedici aile ortamında yetişen çocukların 15 yaşından 21 yaşına kadar suç örüntüsü oluşturdukları gözlemlenmiştir (Fergusson, Swain-Campbell, ve Horwood, 2004). Alan yazında yer alan bir araştırmada ise, antisosyal davranış örüntüsü ile düşük sosyo-ekonomik düzey arasındaki ilişkinin babanın suçlu olma durumu ile bağlantılı olduğu sonucuna varılmıştır (Robin, 1991).

\section{Zekâ Düzeyi ve Okul Başarısı Faktörleri}

Mükerrer suçluluk, düşük zekâ ve düşük akademik başarıyla birlikte görülmektedir. Literatürde yer alan birçok araştırmada düşük akademik başarı ile suç arasında ilişki olduğu tespit edilmiştir (Andrews, Bonta, James ve Hoge, 1990; Wolfgang, 1972). Düşük zekâ düzeyi ve okul başarısı, suçlu örüntünün yanı sıra davranım bozukluğu tanısını da yordamaktadır (Moffitt, 1993). İngiltere'de yapılan ikiz çalışmalarında, sosyal sınıftan ve anne babanın eğitim durumundan bağımsız olarak, düşük zekâ düzeyi ile davranım bozukluğu arasında ilişki bulunmuştur. Farrington (2005)’a göre, dü- 
şük zekâ düzeyinde olan ve antisosyal davranış örüntüsü bulunan suçlular işledikleri suçun sonuçlarını hesaplayamayacak zekâ düzeyinde oldukları için tekrarlı suç örüntüsüne daha yatkın hale gelmektedirler.

Antisosyal kişilik bozukluğu teşhisi konan bireyler üzerinde bir takım nöropsikolojik çalışmalar yapılmıştır. Çalışmalarda kullanılan beyin görüntüleme yöntemleri sonucunda bu bireylerin prefrontal kortekslerinde bazı işlev bozuklukları olduğu gözlemlenmiştir (Ak ve Sayar, 2002). Montreal boylamsal çalışmasının sonuçlarına göre suç işleyen ve işlemeyen bireyler arasındaki en önemli nöropsikolojik ayrım frontal lob'un yürütücü işlevleri üzerinde bulunmuştur. Frontal lobun yürütücü işlevleri ise, bireyin dikkatini, konsantrasyonunu, soyut düşünme, plan yapabilme, dürtüsel davranışları ketleme, kendi davranışlarının sonuçlarını düşünmek şeklindedir (Farrington, 2005). Dolayısıyla, suç işleyen bireylerin bu işlevlerinde sorun olduğu ileri sürülebilir.

Diğer taraftan, literatür incelendiğinde mükerrer suçlular üzerinde beyin inceleme çalışmalarıyla ilgili bulgulara rastlanmamıştır. Fakat mükerrer suçlularda görülen dikkat eksikliği, dürtüsellik ve düşük zekâ düzeyi gibi fonksiyonlar frontal lobun yürütücü işlevleri ile doğrudan alakalıdır (Farrington, 2005). Tüm bu bilgiler 1şı̆̆ında, antisosyal kişilik bozukluğu teşhisi konulan kişilerin ve mükerrer suçluların frontal lob faaliyetleri açısından benzer özellik gösterdikleri, davranım bozukluğu tanısında rol oynayan faktörlerin mükerrer suçluluk oluşumunda da etkili olduğu söylenebilir.

\section{Konu ile İlgili Yaklaşımlar}

Mükerrer suçluluğun daha iyi anlaşılıp, çeşitli önleme çalışmalarının yapılmasında davranım bozukluğu, antisosyal kişilik bozukluğu gibi suç örüntüsünü tetikleyen psikolojik rahatsızlıkların erken yaşta fark edilmesi önem taşımaktadır.

Alan yazında Gelişimsel ve Yaşam Boyu Kriminoloji Teorileri (Developmental and Life-Course Criminology Theories, DLC) bulunmaktadır. Bu teorilerin amacı yaşam boyu süren suç örüntüsünün nedenlerini açılamaktır. Bu genel amacın yanı sıra suç örüntüsünün oluşumunda belirleyici olan risk faktörlerini tespit etmek, kriminal kariyerin gelişiminde önemli olan yaşam olaylarını irdelemektir. 


\section{ICAP (Integrated Cognitive Antisocial Potential Theory) Teorisi}

DLC teorileri arasında, Farrington tarafından geliştirilen Entegre Bilişsel Antisosyal Potansiyel Teorisi (Integrated Cognitive Antisocial Potential Theory, ICAP) bilimsel olarak en sağlam temelleri olan teorilerden biridir.

ICAP teorisi çerçevesinde yapılan son araştırmalara bakıldığında, çocukluktan itibaren gelişim sürecinin suç işleme örüntüsünün oluşumunda çok önemli bir noktada olduğu ispatlanmıştır. Bunun yanı sıra kişinin içinde bulunduğu güncel yaşam şartlarının da suçun işlenmesinde aynı derecede etkili olduğu bulunmuştur (Fox, Jennings ve Farrington, 2015). ICAP teorisi açısından bakıldığında suç kavramı üç parçadan oluşmaktadır. Bunlar; bireysel özellikler, kişinin içinde bulunduğu ortam/çevre koşulları ve son olarak bireysel özellikler ile ortamın etkileşimidir (Farrington, 2005).

ICAP teorisinin odak noktası "antisosyal potansiyel" kavramıdır. Bu kavram bireyin antisosyal davranışlara ve suç işlemeye yönelik meyilini belirlemektedir. ICAP teorisine göre, suç davranışı, uzun süreli antisosyal potansiyeli olan bireyin bilişsel ve gelişimsel özelliklerinin birleşmesiyle meydana gelmektedir. Aynı zamanda kısa süreli antisosyal potansiyeli olan bireyde ise, durumsal faktörler ve suç işlemeye yönelik bir firsat ortaya çıtığında suçun gerçekleştiği bildirilmektedir (Fox vd., 2015).

Uzun süreli antisosyal potansiyele sahip grupta yer alan bireyler, çocukluktan itibaren antisosyal davranışlar sergileyerek ergenlik dönemlerinde daha sık suç işlemeye başlarlar. Aynı zamanda dürtüsellik, düşük okul performansı, sosyal yeteneklerin yetersiz olması, düşük sosyo-ekonomik düzey ve anne babanın ilgisiz olması gibi özellikleri de bünyelerinde barındırırlar. Kısa süreli antisosyal potansiyel grubunda olanlar ise, daha çok yaşıtlarından etkilenip suç işleyenler, alkol ve uyuşturucu madde etkisiyle suça sürüklenenler ve suçlu davranışın sonucunu hesaplayamayanlardan oluşmaktadır. Kısa süreli antisosyal potansiyel kavramı, mükerrer suçlu olup antisosyal kişilik bozukluğu tanısı almayan bireylerin anlaşılmasında etkili olabilmektedir. Uzun süreli antisosyal potansiyel kavramının ise, çocukluktan itibaren süregelen bir antisosyal davranış örüntüsünün mükerrer suçluluğa dönüşümünü açklamakta yardımcı olabileceği düşünülmektedir (Fox vd., 2015).

Bireylerin uzun süreli antisosyal potansiyeli düşük ve yüksek seviyede olabilir. Örneğin, yüksek seviyede uzun süreli antisosyal potansiyeli olan 
birey farklı şartlar altında çok çeşitli suçlar işleyebilmektedir, bunun sebebi ise, hali hazırda uzun süredir antisosyal davranışları bünyesinde tutmasıdır. $\mathrm{Bu}$ bireyler genellikle mükerrer suçlulardan oluşmaktadır ve bunların suç işlemesi için elverişli çevre şartlarının olması gerekmez. Çünkü bunlar her durumda suç işleyebilme potansiyeline sahiptirler. Öte yandan düşük seviyede uzun süreli antisosyal potansiyeli olan bireyin suç işlemesi için çevresel şartlar gerekmektedir. Örneğin, hemen fark edilmeyecek noktada park halinde olan arabada unutulmuş bir çanta varsa, düşük seviyede uzun süreli antisosyal potansiyeli olan birey bunu çalmak isteyebilir. ICAP teorisine göre, düşük seviyede uzun süreli antisosyal potansiyeli olan bireyin suç işleyebilmesi için alkol veya madde kullanması, öfkeli olması, suçlu arkadaş çevresinin olması, işlenen suçun fark edilmemesi (lack of guardiance) gibi k1sa süreli antisosyal potansiyel kategorisinde yer alan etmenlerin bir ya da birkaçının etkisi gerekmektedir (Fox vd., 2015).

Bireyin uzun süreli antisosyal potansiyelinin gelişmesinde etkisi olan risk faktörleri dürtüsellik, düşük okul performansı, sosyal yeteneklerinin düşük seviyede olması, ailede sevgi yoksunluğu ve doğru yönlendirmelerin yapılmamasıdır (Fox vd., 2015). ICAP teorisinin ortaya koymuş olduğu risk faktörleri, ampirik çalışmalar sonucunda tutarlı bulunmuştur. Nitekim Hollanda' da 2009 yılında mahkûmlar üzerinde yapılan bir çalışmada uzun süreli antisosyal potansiyel için ön görülen risk faktörlerinin başarılı bir biçimde suçu tahmin ettiğinin görülmesi söz konusu düşünceyi destekleyen bir bulgudur (Fox vd., 2015).

Yine Florida'da tutuklu bulunan 405 mahkûm üzerinde yapılan bir başka çalışmada ise, suç işleyen bireylerin gelişim evrelerinde karşılaştıkları risk faktörleri ile suç işledikleri anlardaki çevresel şartlar değerlendirilmiştir. Araştırmanın sonucunda, suç işleyen bireylerin yüksek seviyede uzun süreli antisosyal potansiyele sahip olmaları halinde çevre şartlarının etkisi olmaksızın suçlu edimlere yöneldikleri görülmüştür. Diğer taraftan, bireyin uzun süreli antisosyal potansiyeli düşük seviyede olsa da suça elverişli bir çevredeyse suçlu davranışa yöneldiği sonucuna ulaşılmıştır (Fox vd., 2015).

Araştırmalar sonucunda ICAP teorisinin de desteklediği gibi suçlu davranışın ortaya çıkmasında gelişimsel risk faktörlerinin yanı sıra bireyin içinde bulunduğu çevre şartlarının da suçun ortaya çıkmasına imkân tanımasının önemli olduğu görülmüştür. ICAP teorisinin ayırıcı noktalarından bir tanesi, teorinin kısa süreli risk faktörlerini de hesaba katarak, çok ciddi suç- 
lar işleyen suçluların da kriminal davranışlarına bir açılama getirebilmesidir (Fox vd., 2015).

ICAP teorisi suçluların nasıl yetiştiğini açklamakla birlikte suçlular arasındaki farklılıkları da açıklamaktadır. Örneğin bazı suçluların neden bazı durumlarda sürekli olarak suç işlediklerini ve diğerlerinin bu suçu işlemediği sorusuna açılama getirebilmektedir. Bu durumda ICAP teorisini diğer teorilerinden ayıran önemli kısım, neden bazı insanlar mükerrer suçlu olurken diğerlerinin olmadığını açıklamasıdır (Fox vd., 2015).

ICAP teorisine antisosyal kişilik bozukluğu, davranım bozukluğu gibi kavramların entegre edilmesiyle birlikte, suçlular arasında ayrım yapılması ve çeşitli suç örüntülerinin anlaşılması da kolaylaşmıştır. Örneğin teoriye göre, yüksek seviyelerde uzun süreli antisosyal potansiyeli olan birey, hangi şartlar altında olursa olsun suç işleme davranışını gerçekleştirmektedir. $\mathrm{Bu}$ durum mükerrer suçluluk kavramının anlaşılmasına yardımcı olmaktadır. Mükerrer suçlular, ortamın suça elverişli olup olmamasından bağımsız olarak suç işleme döngüsü içerisinde suça sürüklenirler. Böylece ICAP teorisi, neden bazı suçluların mükerrer suçlu kategorisinde yer aldığı sorusunu 'uzun süreli antisosyal potansiyel kavramı' ile açıklar (Fox vd., 2015).

\section{Moffitt Gelişimsel Sınıflandırma Teorisi}

Moffitt tarafından 1993 yılında suçluların yaş-suç oranı eğrisinden yola çıkarak türettiği Gelişimsel Sınıflandırma Teorisi suçlu ve sapkın davranışları daha anlaşılır kılmak amacı ile ortaya çıkmıştır. Yaş-suç oranı eğrisine göre suçluların büyük bir kısmı gençlerden oluşmakta, geriye kalan küçük ve kalıplaşmış bir grup ise yetişkinlerden meydana gelmektedir. Moffitt, oluşturduğu teorisinde yaş-suç oranı eğrisini desteklemektedir. Gelişimsel Sınıflandırma Teorisi'ne göre de suçluların büyük bir kısmı ergen, genç bireylerden oluşur, kalan küçük suçlu oranları yetişkinler tarafından doldurulur (Farrington, 1986; Hirschi ve Gottfredson, 1983).

Moffitt'e göre iki tip suçlu bulunur ilki 'ergenlikle sinırlı suçlular' (Adolescence-limited, AL); bunlar, işledikleri suçları çoğunlukla ergenlik döneminde işleyen suçlulardır. İkinci tip suçlular ise, 'yaşam boyu sürekli suç işleyenler' (Life-consistent persistent, LCP)'den oluşmaktadır. Moffitt'e göre, yaş-suç eğrisinde oranın ergenlikte en yüksek noktaya ulaşmasının nedeni 'yaşam boyu süren suç' kategorisinde yer alan suçlulara 'ergenlikle sınırlı 
suç' kategorisinde bulunan suçluların katılmasıdır. Ergenlikle sınırlı suç kategorisinde yer alan suçluların ilerleyen yaşlarda suçu bırakmasıyla birlikte yaş-suç eğrisinde, yaşam boyu süren suç kategorisinde bulunan suçlular kalmaktadır (Fox vd., 2015).

Moffitt, ergenlikle-sınırlı suçlu grubunda bulunanların akran baskılarından dolayı üyesi bulundukları grubun normlarını daha çabuk kabul etme eğilimindedirler. Bu yüzden küçük suçlar işlemeye daha yatkın olurlar. Örneğin, mağazalardan yiyecek aşırma, kavgaya karışma gibi suçları işleyebilirler. Bazı durumlarda ise, yetişkin tarzı davranışlar olan alkol ve madde kullanma, küçük yaşta cinsel ilişkiye girme gibi davranışlar sergileyebilirler (Moffitt, 1993).

Yaşam-boyu süren suç grubunda olan suçlularda suç işleme davranışı çok erken yaşlarda başlamaktadır. Suç işleme davranışı bir örüntüye dönüşerek uzun yıllar devam eden süreklilik kazanabilmektedir (Farrington, 1993; Moffitt, 1993). Yaşam boyu süren suç grubunda yer alan suçluların etiyolojisi incelendiğinde kendilerinde nöropsikolojik eksiklikler ve biyolojik ve hormonal düzensizliklerin olduğu tespit edilmiştir. Sürekli suç işleme örüntüsünün oluşumunda nöropsikoloijk eksiklerin üzerine olumsuz sosyal çevre koşullarının (ilgisiz aile, düşük sosyo-ekonomik düzey, düşük okul başarısı vb.) da eklenmesinin büyük oranda etkisi olduğu düşünülmektedir (Piquero vd., 2012).

Literatürde Moffitt' in teorisinde yer alan 'ergenlikle-sınırlı suç' ve 'yaşam boyu süren suç' tiplerini ampirik açıdan doğrulayan birçok çalışma mevcuttur. Fakat bunların yanı sıra daha fazla suç tipinin (düşük seviyeli kronik suçlular ve iyileşme gösteren suçlular) bulunduğu çalışmalar da mevuttur (Moffitt, 2006; Piquero ve Moffitt, 2005).

Suçluların gelişimi üzerine yürütülen Cambridge araştırmasında yer alan 400 çocuk, 48 yaşına kadar suç işleme durumları ve antisosyal davranış örüntüleri açısından incelenmiştir. Çalışmanın sonucunda çocukların sahip oldukları bireysel özellikler ile çevre koşullarının getirdiği risk faktörlerinin antisosyal davranışlar ile arasında pozitif korelasyona sahip olduğu görülmüştür. 400 suçlu içerisinde en yüksek antisosyal davranış puanına sahip olanların mükerrer suçlular, düşük seviyeli kronik suçlular ve suç oranı ergenlikte en yüksek seviyede yer alanlar olarak bulunmuştur (Piquero vd., 2012). Bu çalışmanın sonucuna göre mükerrer suçluların antisosyal kişilik bozukluğu ile ilintili olduğu, bu durumda bunların Moffitt'in teorisinde yer 
verdiği 'yaşam boyu süren suçlu' tipinde yer aldığı belirtilmektedir. Diğer taraftan, Moffitt'in Gelişimsel Sınıflandırma Teorisi'nde 'ergenlikle sınırlı suç grubu'nda bulunanların suçlu edimlerle olan ilişkisi açıklanmaktadır. Yaşam boyu süren suç grubu ile antisosyal kişilik bozukluğu arasındaki ilişki de saha çalışmaları ile kanıtlanmaktadır.

\section{Sonuç}

Davranım bozukluğu tanısı antisosyal kişilik bozukluğu tanısının temelini oluşturmaktadır. Yurt içi literatürde bulunan çalışmalara bakıldığında mükerrer suçluluk ile antisosyal tutumlar arasındaki ilişkinin önemsendiği görülmektedir. Bunun yanı sıra davranım bozukluğu tanısı ele alınmadan sadece çocukluk dönemindeki yaşantının mükerrer suçluluğa etki edebileceği belirtilmiştir. Bu çalışmada hem mükerrer suçluluğa hem de davranım bozukluğuna etki eden çeşitli faktörler ele alınmıştır. Davranım bozukluğu tanısına sahip bireyin tekrarlayan suç örüntüsü oluşturmaya olan eğilimi, çeşitli boylamsal çalışmalarla saptanmıştır. Çok erken yaşlarda suç işlemek, örneğin işlenen suçun hırsızlık olması mükerrer suçluluğu tahmin eden faktörler olarak görülmektedir. Bahsi geçen bu faktörler aslında davranım bozukluğu tanısına sahip bireylerin söz konusu psikolojik bozukluk sonucunda sergiledikleri davranışların bir sonucudur. Reddedici aile ortamında, ailede suçla ilintili bireylerin olduğu ortamda, düşük sosyo-ekonomik düzeyde büyüyen çocukların davranım bozukluğu geliştirme ihtimalleri iki kat artmaktadır. Bu şartlar altında davranım bozukluğu teşhisi alan birey, bir sağaltım planı yapılmadığı ve içinde bulunduğu ortam değişmediği sürece davranım bozukluğu sonucu insanlara, eşyalara, hayvanlara zarar verme, çalma, gasp etme gibi davranışları sürekli tekrar eden bir örüntüye sahip olacaktır. Bu durumda bireyin mükerrer suçlu olarak tanımlanması çok yüksek bir olasılıktır. Davranım bozukluğu tanısının yanı sıra DEHB tanısına sahip bireylerin de mükerrer suçluluğa olan yakınlığı çeşitli boylamsal çalışmalarla örneklendirilmiştir.

Mükerrer suçluluğun gelişimini daha iyi anlamak ve gerekli önleyici çalışmaları yapabilmek için Gelişimsel Yaşam Boyu Kriminoloji Teorileri oluşturulmuştur. Bu çalışmada Farrington tarafindan oluşturulan 'ICAP Teorisi' ve Moffitt'in 'Gelişimsel Sınıflandırma Teorisi'nden bahsedilmiştir. ICAP teorisine göre mükerrer suçluluğun gelişimi bireyin özelliklerine, çevre şart- 
larına ve bu değişkenlerin birbirleriyle olan ilişkisine göre şekillenmektedir. Birey antisosyal özelliklere sahipse ve çevre şartları sürekli antisosyal özellikleri tetikliyorsa, mükerrer suçlu olma ihtimali çok yüksektir. Öte yandan, bireyde antisosyal eğilimler az olsa da içinde bulunduğu çevresel şartlar suça eğilim yaratıyorsa, kişi hayatının belli bir döneminde suç işleyebilir. Moffitt'in Gelişimsel Sınıflama Teorisi'nde suçlular iki sınıfa ayrılmaktadır. Bunlar 'ergenlikle sınırlı suçlar' ve 'yaşam boyu süren suçlar'dır. Moffitt'e göre, ergenlikle sınırlı suçlar kategorisinde yer alan kişiler, ergenlik dönemlerinde suç işleme düzeyleri en yüksek seviyeye ulaşır ve zamanla suçtan vazgeçerler. Yaşam boyu süren suçlar kategorisinde ise, suç işleme davranış1 çocukluktan itibaren başlayarak yaşam süresince devam eder. Bu grupta yer alanlar çoğunlukla mükerrer suçlulardır.

ICAP ve Gelişimsel Sinıflandırma Teorileri'nde mükerrer suçluluğun oluşmasındaki risk faktörleri ilgisiz aile ortamı, düşük sosyo-ekonomik durum, düşük okul başarısı, antisosyal kişilik özellikleridir. Bu çalışmada bahsi geçen mükerrer suçluluğun davranım bozukluğu ve antisosyal kişilik bozukluğu ile ilişkisini yordayan risk faktörleri de ICAP ve Gelişimsel Sınıflama Teorileri'nin mükerrer suçlulukla ilintili gördüğü risk faktörleri ile örtüşmektedir.

Yapılan bu çalışmanın sonucunda davranım bozukluğu tanısını hızlandıran ve mükerrer suçluluğa yol açan faktörlerin önemi vurgulanmıştır. Belirlenen faktörler çoğunluğu yurt dişı literatürde yapılmış olan çalışmaların sonucunda elde edilmiştir. Diğer taraftan, yurt içi literatürde davranım bozukluğu tanısına sahip olan ve suç işlemiş bireyler üzerinde boylamsal çalışmalara daha sık yer verilmesi gerektiğini düşünüyoruz. Böylece Türkiye örnekleminde hangi faktörlerin daha ön planda olduğu tespit edilerek çeşitli sağaltım planları hazırlanabilir.

Sonuç olarak, davranım bozukluğu ve antisosyal kişilik bozukluğunun etkilerini minimum düzeyde tutarak mükerrer suçluluk örüntüsüne dönüşmesini engellemek adına birtakım önlemler alınmalıdır. Öncelikli olarak davranım bozukluğu ve antisosyal kişilik bozukluğu tanısına sahip bireylerin aile üyelerine bu psikolojik bozukluk üzerine psikolojik eğitimler verilmelidir. Bireyin çevresinde bulunan kişilerin bireyin sergilediği suç ve şiddet davranışlarının aslında davranım bozukluğu ve antisosyal kişilik bozukluğu rahatsızlığının bir parçası olduğunu bilmesi, rahatsızlığın iyileştirilmesinde veya kötüye gitmesini önlemede önemli bir adım olacaktır. 
Öte yandan davranım bozukluğu tanısı alan çocukların eğitim hayatları, hem anne-babaları hem de okulların rehberlik servisleri tarafindan dikkatle takip edilmelidir. Davranım bozukluğu tanısından mustarip olan çocuklar okula tutunmayı başarabilirlerse mükerrer suçlu olma ihtimallerinin de azalacağ1 düşünülmektedir. Burada okulda bulunan öğretmenlere büyük görevler düşmektedir. Öğretmen, anlayışlı, sabırlı ve iyi iletişim kurmaya istekli olmalıdır. Çocukları rencide edici davranışlardan ve cezalandırma sistemlerinden kaçınmalıdır. Şiddet dışında başka iletişim yollarının da olduğu çocuklara göstermelidir. Ülkemizde her ilde yer alan Halk Eğitim Merkezleri'nde ebeveyn tutumları, aile içi iletişim, çocukların temel duygusal ihtiyaçları üzerine eğitimlerin düzenlenmesi, davranım bozukluğu tanısı olan veya olmayan bütün çocuklar için daha sağlıklı bir büyüme ortamının oluşmasına katkı sağlayacaktır.

Özellikle davranım bozukluğu tanısına sahip olan çocukların daha sağlıklı bir aile ortamında büyümelerinin, onların mükerrer suçluluktan uzaklaşmalarına yardımcı olacağı düşünülmektedir. Anne ve babanın ruh sağlığı çocukların suça sürüklenmesinde ve davranım bozukluğu tanısının oluşumunda etkilidir. Bu durumda anne ve babanın ruh sağlığının daha iyi ve dengeli bir duruma getirilmesi için Toplum Ruh Sağlığı Merkezleri hakkında bilgiler verilerek bu merkezlerde anne ve babalar için düzenlenen çeşitli sağaltım çalışmalarının sıklığı artırılmalıdır. Anne ve babanın ebeveynlik yöntemleri ve ruh sağlığı üzerine çalışmalar yapıldığı takdirde davranım bozukluğuna genetik yatkınlığı olan çocukların tanı alma ihtimallerinin düşeceği düşünülmektedir. Davranım bozukluğu tanısına sahip olan ve hüküm giymiş bireylerin, cezaevlerinde çeşitli meslek edinme programlarına katılmaları desteklenmelidir. Böylelikle düşük gelir düzeyinin bireyin mükerrer suçlu olmasındaki payı önlenebilecektir.

$\mathrm{Bu}$ çalışmanın sonucundan hareketle davranım bozukluğu tanısının mükerrer suçluluk örüntüsüne dönüşmesini engellemek adına çeşitli önerilerde bulunulmuştur. Bu öneriler toplumda yer alan ve farklı işlevleri olan kurum ve kuruluşların, kişilerin yapabileceği çeşitli çalışmaların önemine vurgu yapmaktadır. 
EXTENDED ABSTRACT

\title{
A Review on the Common Variables of Repetitive Guilt, Behavioral and Antisocial Personality Disorders
}

\author{
Beril Yavuz Bozdoğan - Müjdat Avc1 \\ Osmaniye Korkut Ata University
}

Crime is a part of human nature. Society has limited balance and sometimes that balance gets broken and as a result, criminal behavior pattern occurs. Crimes have multiple dimensions. It's not only related to law or justice, but also has sociological and psychological aspects. At the beginning of searching crime behavior; researchers evaluate the criminal behaviors in interactions between a couple of factors like socioeconomic status, environmental factors, and etc. When it came to 20th century, there was a room opening for psychology, specifically personality disorders. Among the all personality disorders; Antisocial Personality Disorders got the highest attention. As a result of one study; there were \%71 offenders having Antisocial Personality Disorders and they started crime earlier age, they continued to repeat the crime behavior. Some of the research shows that; Conduct Disorder and Antisocial Personality Disorder have a relationship with juvenile delinquency. The diagnosis of Conduct Disorder and Antisocial Personality Disorder is made by psychiatrists, according to the criteria in the Diagnostic and Statistical Manual of Mental Disorders, DSM-5. According to DSM-5; 15 diagnostic criteria to be provided for the diagnosis of behavioral disorder have been collected under four main titles. The titles are as follows; aggressive attitudes towards humans and animals, demonstrating damage to property, fraud or theft and violating the rules to a great extent. An important point is that these behaviors disrupt one's work, school and social life. It is diagnosed as Antisocial Personality Disorder if the person is 18 years old or older and meets the criteria for conduct disorder diagnosis. Juvenile delinquency characterizes individuals who repeatedly commit a crime after crime even after leaving the prison. Considering all these information, this study purposes to evaluate the 
juvenile delinquency pattern in the perspective of Conduct Disorder and Antisocial Personality Disorder. The effects of certain variables are mentioned in individuals who once committed a crime to make these actions into a chronic crime pattern. These variables are: age, their first criminal behavior, family attitude and family structure, socioeconomic status, intelligent level and school success. To better understand the Juvenile Delinquency and to carry out various prevention activities, it is important to recognize psychological disorders that trigger the crime patterns such as Conduct Disorder and Antisocial Personality Disorder at an early age. For this purpose; researchers studied theories about Developmental and LifeCourse Criminology (DLC) Theories. Among the DLC theories, Integrated Cognitive Antisocial Potential Theory (ICAP) developed by Farrington is one of the most scientifically solid theories. The focus of ICAP theory is the concept of "antisocial potential". This concept determines the individual's inclination towards antisocial behaviors and crimes. According to the ICAP theory, crime behavior occurs by combining the cognitive and developmental characteristics of the individual with long-term antisocial potential. It also states that the crime occurs when an individual with short term antisocial potential faces with situational factors which provide an opportunity to commit a crime. Individuals in the long-term Antisocial Potential group exhibit antisocial behaviors from childhood and begin to commit crime more often during adolescence. At the same time, they have features such as impulsivity, low school performance, insufficient social skills, low socioeconomic level, and unrelated parents. Those in the shortterm antisocial potential group are the ones who are mostly affected by their peers to commit crime by being dragged into crime with the effect of alcohol, drugs so that they cannot calculate the outcome of their criminal behavior. Long term antisocial potential concept: It is believed that it can help explain the transformation of an ongoing antisocial behavior pattern from childhood to repeated criminality. With the integration of concepts such as Antisocial Personality Disorder and Conduct Disorder into the ICAP theory, it has been facilitated to distinguish between criminals, and to understand various crime patterns. For example, according to the theory, an individual with high levels of long-term antisocial potential performs a crime behavior under any circumstances. This situation helps to understand the concept of repeating criminality. The ICAP theory explains 
why some criminals are in the repeat criminal category with the concept of long-term antisocial potential. The Developmental Taxonomy Theory derived by Moffitt in 1993 based on the age-crime rate curve of criminals has been developed in order to make criminal and deviant behavior more understandable. According to the age-crime rate curve, the majority of offenders are young people, while the remaining small and stereotyped group consists of adults. According to Moffitt, there are two types of criminals; The first one is Adolescence-limited (AL), the delinquents who mostly commit crimes during their adolescence. The second type of criminals are those who commit life-consistent persistent (LCP) crime. According to Moffitt, the reason for reaching the highest point in adolescence in the age crime curve is the inclusion of criminals in the adolescence-limited crime category for those who are in the category of lifelong crime. As criminals in adolescence-confined crime quit the crime at an older age, the criminals of the lifetime type remain in the age crime curve. In this study, various factors affecting both repetitive criminality and Conduct Disorder, Antisocial Personality Disorder are discussed. The tendency of the individual with the diagnosis of Conduct Disorder to form a recurrent crime pattern has been determined by various longitudinal studies. To commit a crime at a very early age are seen as factors that predict juvenile delinquency. These factors are actually the behaviors of individuals with a diagnosis of Conduct Disorder as a result of this psychological disorder. Children who grow up in a rejecting family environment, in an environment with crime-related individuals in the family and at a low socioeconomic level are more likely to develop Conduct Disorder. Under these circumstances, the individual who is threatened with Conduct Disorder, unless a treatment plan is made and the environment in which it is located does not change, the behaviors will be repeated such as harming, stealing, extortion of people, goods, animals brought by the Conduct Disorder. In this case it is very likely that the individual will be identified as a repeat offender.

In this study, the risk factors predicting the relationship between the repetitive guilt and Behavioral Disorder and Antisocial Personality Disorder also coincide with the risk factors seen by ICAP and Developmental Taxonomy Theories related to juvenile delinquency. 
As a result of the study, recommendations have been made to reduce the effects of Conduct Disorder and Antisocial Personality Disorder, which will prevent the repetitive pattern of criminality. Providing psychoeducation to families and teachers about these psychological diagnoses can be an important step. Community Mental Health Centers should be used to make the mental health of parents more balanced. Based on the results of this study, various suggestions have been made to prevent the diagnosis of Conduct Disorder and Antisocial Personality Disorder from turning into a repeated guilt pattern. These suggestions emphasize the importance of various activities that can be done by institutions and organizations with different functions in the society.

\section{Kaynakça / References}

Ak, K. S. (2002). Antisosyal kişilik bozukluğunda sosyobiyolojik etkenler. Bull Clin Psychopharmacol, 12, 155-158.

Algül, A., Semiz, Ü. B., Ateş, M. A., Başoğlu, C., Doruk, A., Ebrinç, S., ve Çetin, M. (2007). Antisosyal kişilik bozukluğu olan bireylerde madde kullanımı ve saldırganlık ilişkisi. Düşünen Adam, 20, 141-150.

Anayurt, Ö. (2001). Hukuka giriş ve hukukun temel kavramları. Seçkin Yayıncllı.

Andrews, D. A., Bonta, James ve Hoge, R. D.(1990), Classification for effective rehabilitation: rediscovering psychology.Criminal Justice and Behavior, 17,19-52.

Brennan, P. A., Mednick, B. R., ve Mednick, S. A. (1993). Parental psychopathology, congenital factors, and violence. Mental Disorder and Crime, 244-261.

Brennan, P. A., Mednick, S. A., ve Hodgins, S. (2000). Major mental disorders and criminal violence in a Danish birth cohort. Archives of General Psychiatry, 57(5), 494-500.

Cömert, Ö. (2018). Mükerrer çocuk suçluluğu: Bitlis ili örneği. Yayınlanmamış Yüksek Lisans Tezi, Firat Üniversitesi, Elazığ.

Dönmezer, S. (1984). Kriminoloji, Filiz Kitabevi, İstanbul.

Duncan, R. D., Kennedy, W. A. ve Patrick, C. J. (1995). Four-factor model of recidivism in male juvenile offenders. Journal of Clinical Child Psychology, 24(3), 250-257.

Farrington, D. P. (1983). Offending from 10 to 25 years of age. Prospective studies of crime and delinquency içinde (s. 17-37). Springer, Dordrecht.

Farrington, D. P. (1986). Age and crime. Crime and justice, 7, 189-250. 
Farrington, D. P. (2005). Childhood origins of antisocial behavior. Clinical Psychology $\mathcal{E}$ Psychotherapy: An International Journal of Theory $\mathcal{E}$ Practice, 12(3), 177-190.

Farrington, D. P. ve Wikstrom, P. O. H. (1994). Criminal careers in London and Stockholm: A cross-national comparative study. Cross-national longitudinal research on human development and criminal behavior içinde (s. 65-89). Springer, Dordrecht.

Farrington, D. P., Coid, J. W., Harnett, L., Jolliffe, D., Soteriou, N., Turner, R. ve West, D. J. (2006). Criminal careers up to age 50 and life success up to age 48: New findings from the Cambridge study in delinquent development (Vol. 94). Home Office Research, Development and Statistics Directorate, London, UK.

Fergusson, D., Swain-Campbell, N., ve Horwood, J. (2004). How does childhood economic disadvantage lead to crime?. Journal of Child Psychology and Psychiatry, 45(5), 956-966.

Fox, B. H., Jennings, W. G., ve Farrington, D. P. (2015). Bringing psychopathy into developmental and life-course criminology theories and research. Journal of Criminal Justice, 43(4), 274-289.

Fridell, M., Hesse, M., Jæger, M. M., ve Kühlhorn, E. (2008). Antisocial personality disorder as a predictor of criminal behaviour in a longitudinal study of a cohort of abusers of several classes of drugs: relation to type of substance and type of crime. Addictive Behaviors, 33(6), 799-811.

Güler, G. (2017). Suça sürüklenen çocukların biyopsikososyal değerlendirilmesi. Türkiye Klinikleri J Child Psychiatry-Special Topics, 3(3), 220-4.

Hare, R. D. ve Neumann, C. S. (2009). Psychopathy: Assessment and forensic implications. The Canadian Journal of Psychiatry, 54(12), 791-802.

Hirschi, T. ve Gottfredson, M. (1983). Age and the explanation of crime. American Journal of Sociology, 89(3), 552-584.

Kalenderoğlu, A., Yumru, M., Selek, S. ve Savaş, H. A. (2007). Gaziantep Üniversitesi tıp fakültesi adli psikiyatri birimine gönderilen olguların incelenmesi. Nöropsikiyatri Arşivi.

Kızmaz, Z. (2006). Şiddetin sosyo-kültürel kaynakları üzerine sosyolojik bir yaklaşım. Fırat Üniversitesi Sosyal Bilimler Dergisi, 16(2), 247-267.

Loeber, R., ve Farrington, D. P. (1998). Serious and violent juvenile offenders: Risk factors and successful interventions. Sage Publication. 
Maner, F., Kayatekin, Z. E., Abay, E., Saygili, S., ve Sener, A. I.(1991).Psikiyatrik hastaliklar ve suç. Düsünen Adam, Psikiyatri ve Nörolojik Bilimler Dergisi,4,6-13.

McCord, J. (1979). Some child-rearing antecedents of criminal behavior in adult men. Journal of Personality And Social Psychology, 37(9), 1477.

Moffitt, T. E. (1993). The neuropsychology of conduct disorder. Development and Psychopathology, 5(1-2), 135-151.

Murray, J., ve Farrington, D. P. (2010). Risk factors for conduct disorder and delinquency: key findings from longitudinal studies. The Canadian Journal of Psychiatry, 55(10), 633-642.

Muş, E. (2016); Türkiye'de suç istatistikleri, kriminoloji suç teorileri ve uygulamalar. (Edt; Muş, E.), Ankara:Karınca Yayınları.

Mutlu, C., Özdemir, M., Yorbik, O. ve Kilicoglu, A. G. (2015). Possible predictors of hospitalization for adolescents with conduct disorder seen in psychiatric emergency service. Düşünen Adam, 28, 301-8.

Öncü, F., Soysal, H., Uygur, N., Özdemir, F., Türkcan, S., Yeşilbursa, D., ve Alataş, G. (2002). Zorunlu klinik tedavi sonrası yineleyici suç işleyen adli psikiyatri olgularının tanı ve suç niteliği açısından değerlendirilmesi. Düşünen Adam, Psikiyatri ve Nörolojik Bilimler Dergisi, 15(3), 132-48.

Öztürk, M. O, Uluşahin A. (2016) Ruh sağ lığı ve bozuklukları. Nobel Tıp Kitapları.

Piquero, A. R., ve Moffitt, T. E. (2005). Explaining the facts of crime: How the developmental taxonomy replies to Farrington's invitation. Integrated Developmental and Life-Course Theories of Offending, 51-72.

Piquero, A. R., Farrington, D. P., Fontaine, N. M., Vincent, G., Coid, J. ve Ullrich, S. (2012). Childhood risk, offending trajectories, and psychopathy at age 48 years in the Cambridge Study in Delinquent Development. Psychology, Public Policy, and Law, 18(4), 577.

Robins, L. N. (1978). Sturdy childhood predictors of adult outcomes: Replications from longitudinal studies, 8(4).

Robins, L. N. (1991). Psychiatric disorders in America. The Epidemiologic Catchment Area Study.

Rothbaum, F. ve Weisz, J. R. (1994). Parental caregiving and child externalizing behavior in nonclinical samples: A meta-analysis. Psychological Bulletin, 116(1), 55.

Saldırım, M. ve Karacık, N. (2001). Suça itilmiş çocukların yeniden sosyalizasyonu projesi bildirileri. I. Ulusal Çocuk ve Suç: Nedenler ve Önleme Çalışmaları Sempozyumu, Unicef, 1-311. 
Sardoğan, M. E. ve Kaygusuz, C. (2006). Antisosyal kişilik bozukluğu tanısı almış ve almamış olan bireylerin duygusal zekâ düzeyleri açısından incelenmesi. Ege Ĕ̆itim Dergisi, 7(1), 85-102.

Vaillant, G. E. ve Vaillant, C. O. (1981). Natural history of male psychological health: X. Work as a predictor of positive mental health. The American Journal of Psychiatry.

Wolfgang, M. E., Figlio R. ve Sellin, T. (1972). Delinquency in a birth cohort. Chicago: University of Chicago Press.

Yılmaz, C. (2018). Kriminolojik açıdan akıl hastalı̆̆ı ve suç. Marmara Üniversitesi Hukuk Fakültesi Hukuk Araştırmaları Dergisi, 24(2), 743-765.

\section{Kaynakça Bilgisi / Citation Information}

Yavuz Bozdoğan, B. ve Avc1, M. (2020). Mükerrer suçluluk, davranım bozukluğu ve antisosyal kişilik bozukluğu'nun ortak değişkenleri üzerine bir derleme. OPUS-Uluslararası Toplum Araştırmaları Dergisi, 15(24), 2912-2936. DOI: 10.26466/opus.687095 